MAQ Special Issue - Introduction

\title{
Towards Intergenerational Ethnography: Kinship, Cohorts and Environments in and beyond the biosocial sciences
}

Connections between generations are increasingly understood as fundamental to individual, collective and ecological well-being. We live, as Michelle Murphy puts it, in 'intergenerational times' (2017), when the traumas, infrastructures and exposures of the past as well as the structural inequities of the present are linked to un/livable futures. In a moment of growing concerns about planetary survival including environmental toxicity, climate change, and diminishing biodiversity, attention to intergenerational relations has taken on renewed urgency. Such urgency comes to the fore in worry about endangerment and extinction, environmental health, and the state of the planet we are leaving for future generations (Choy 2011; Dow 2016; Hoover 2018).

Attention to the potential role of kinship in protecting the world and its creatures from further ecological devastation has brought to the fore calls to action, and even pleas to "make kin, not population" (Haraway 2016; Clarke and Haraway 2018). But such discussion about kinship's role in interdependent environmental futures has also brought up debate and contestation. Whilst strongly resisting discourse and practices which centre on individualised responsibility, scholars such as Michelle Murphy highlight the need to problematise the key terms of emerging discussions of kinship. This includes the relevance and limitations of concepts such as 'population' (Murphy 2018). Rethinking the generative intersections between reproductive rights and environmental justice today means also addressing the myriad ways in which kin have been 'unmade' in the past and continue to be in the contemporary present (Subramaniam 2018; Dow and Lamoreaux 2020). Colonial and eugenic legacies still resonate in efforts to address family planning and environmental change in the global south (Sasser 2018). At the same time particular forms of 'kinfulness' 
may be the afterlife of social struggles that diverse histories of oppression and genocide have engendered (Benjamin 2018).

Situated alongside and in dialogue with these discussions of making and unmaking kin, this special issue explores how anthropology might ethnographically examine and engage with intergenerational dynamics across scales and spheres of life. Here, kinship is understood as not just an anthropological object and analytic (Strathern 1992). It is also a means of understanding and addressing the urgency of environmental changes through the recognition and cultivation of intergenerational interdependencies. Given this reimagining of kinship, might a more intergenerationally attuned ethnography become increasingly necessary? How might medical anthropology in particular build on a history of attention to kinship, property and other forms of transmission in ways that account for the increased importance of multispecies and intergenerational 'entanglement' (Nading 2014; Roberts 2019)? Finally, how might anthropologists examine emerging understandings of the essential interdependency of human, animal and planetary health, whilst also recognising the longstanding importance given to such interconnectedness in, for instance, Indigenous histories and ontologies (Todd 2016)?

Entangled embodiments and interconnected social and physical worlds have become a starting point for anthropologists, within and beyond medical anthropology. Recent work that explores how modes of symbiotic co-existence extend between all living communities is exploding and rewriting understandings of the spatial and temporal scale of 'kinful' relations across very different fields of science and biology (Haraway 2015). This includes, for example, a necessary recognition of humans as 'holobionts', exquisitely evolved, both becoming and developing in co-existence with myriad microbial communities (Lormier 2019, Gilbert et al 2012; Benezra et al 2012). An explosion in the study of environmental influences on bodies and health has resulted in a dramatic increase in "biosocial" research, which has become both an anthropological method and an object of study. Developments in 
biosocial research powerfully reinvigorate anthropological observations on kinship's "biological relativity" (Franklin 2013). They bring to the fore enduring anthropological engagement with descent, heredity, and inheritance (Feeley Harnik 2019) as well as more recent work examining the 'substance' and the materialization of relatedness (Carsten 2011, Mckinnon 2016). In medical anthropology specifically, scholars ask how emerging scientific understandings of health often explore the ways social histories constitute environments inside us as inherited metabolic patterns, or what Hannah Landecker has termed the 'biology of history’ (2016, see also Solomon 2016).

This special issue draws from these recent conversations about biosocial kinship, as well as anthropology's long history of engagement with relatedness (Strathern 1992). It seeks to further historicise and situate the evolving meanings of heredity and generation (Müller-Wille and Rheinberger 2007), whilst also extending work that explores how to address intergenerational and multi-species relatedness at a moment often characterized as the Anthropocene (Tsing et al 2017). This includes examining the changing relationship between environmental politics and reproduction (Lappé, Jeffries Hein and Landecker 2019; Hoover 2018), as well as the essential relevance of reproductive politics to all spheres of social life, including the health effects of climate change (Briggs 2017). Intergenerational relationality is, then, a kind of kinship that is increasingly being put to multiple uses by actors with various investments in and approaches to the biosocial study of environmental effects. It is important, then, at this moment to ask whether medical anthropologists want to move toward methodological and theoretical approaches that can attune to intergenerational connections, and if so, how?

The issue brings together medical anthropologists and science and technology studies scholars conducting research in Bangladesh, Canada, China, the United Kingdom, South Africa and the United States as they reflect on how intergenerationality is put to use in settings of diverse knowledge production and dissemination. This includes ethnographic 
research on practices of seed collecting, epigenetic research, birth cohort studies, social policy generation, and clinical trials. Contributors consider how intergenerational relations and modes of transmission take form in and through the everyday practices of biosocial researchers as well as environmental activists. Collectively their ethnographic research allows readers to think through a number of questions. Is the move towards intergenerational ethnography a critical reproach to biosocial research, an opportunity to consider the spatio-temporal assumptions of anthropology, or perhaps both? What might an intergenerational turn at a moment of heightened concern about environmental health mean for medical anthropology, both theoretically and methodologically?

\section{Intergenerational Ethnography as Method in Medical Anthropology}

Growing out of cross-cultural research which argued that there was more to illness than disease, many early approaches to medical anthropology saw a potential to improve the clinical experiences of patients through a more holistic emphasis on healing. In its later, critical guise, medical anthropology distanced itself from the clinic, disentangling from a complementary approach to emphasize the potential harm of biomedical practice, both in theory and practice. More recently, however, as the "tenacious assumptions" (Gordon 1988) of biomedicine shift to an understanding of bodies and biology as developing in context, medical anthropologists are finding new ways to collaborate and simultaneously think critically about and with physicians and natural scientists. Methodological experiments such as Liz Roberts 'bioethnography' (2019) play with boundaries that often manifest in disciplinary terrains. Such work is potentially productive in that it can push qualitative findings into the purview of the biological sciences while continuing to expand the kinds of evidence that medical anthropology might consider relevant to ethnography. As Michelle Murphy puts it, and as both the contributions by Martine Lappé and Robbin Jeffries Hein as well as Janelle Lamoreaux take up, this is a process of simultaneously working 'with and against technoscience' (Murphy 2017). The stakes of such work are heightened at a 
moment when climate change, increasing toxic exposure and, most recently, the Covid-19 pandemic demand renewed attention to social organization and political-economy from scientists across the board. In an effort to simultaneously attend to physical and cultural worlds, medical anthropologists have become reinvested in experiments with multi-modal, collaborative biosocial research (Roberts 2020). Here, we consider how the emerging analysis and reimagination of intergenerational biosocial relations offer anthropologists a further opportunity to reimagine and retool the temporal imaginaries and scalar propensities that underlie ethnographic methods.

Ethnographic research that repeatedly follows and engages with the lives of multiple generations in real time over the course of many years, whilst not widespread, is part of earlier work in medical anthropology focused primarily on local cultures of illness within small scale communities (see for instance Last 2019). The rich possibilities of long-term ethnography have also been explored by those working over many years with the same community or multiple cohorts in a single setting (for example Yan 2009; Rofel 1999), and those formally working alongside epidemiologically focused longitudinal cohort research (Behague 2021, Roberts 2019). While such "birth cohort studies" provide a potential context for further critical intergenerational ethnographic research, in this special issue we demonstrate the possibilities of ethnography through multiple intergenerational lenses that include but also move beyond the specific affordances of longitudinal work with single or multiple generations. Each of the contributions to this special issue analyses the practices of experts outside of anthropology who explicitly attend to more than one generation in their professional research, volunteer activities, and/or everyday practices. In examining how intergenerational transmission is constituted within various fields of biosocial research or environmental practice, authors foreground questions that push medical anthropologists to become more cognizant of how diverse temporalities as well as ideas of kinship, 
personhood and their boundaries, are at work in new and old modes of ethnographic enquiry.

For example, how might attuning to the intergenerational composition of the human through other humans and non-humans—such as the microbes discussed by Amber Benezra or the toxic exposures described by Lamoreaux in this issue-speak back to ideas of kinship that remain centered on homo sapiens? How are understandings of classic concepts in medical anthropology such as embodiment reworked through attention to how environmental exposures and illness experiences extend beyond and even correlate across generations -what anthropologist Emma Bunkley (2021) calls "interembodiment”? Could the rise in nonanthropologists conceptualizing etiologies of disease and deviance as relational signal that it is time to reconsider medical anthropology's ethnographic methodologies (Leighton and Roberts 2020)? Might an anthropological theory of practice for today's changing climate need more attention to how precarity and potentiality (Taussig et al 2013) contribute to the un/making of intergenerational relations in human and non-human worlds? through critical analyses of environmentalism, public health and epigenetic research we seek to open such questions of scope and method, and to expand and reorientate the possibilities and potential of intergenerational ethnography.

\section{Revisiting Kinship in Intergenerational Times}

Studies of kinship have long been recognized as both foundational to anthropology and also subject to heated debates about their ongoing relevance and meaning for the discipline (Bamford 2019). The centrality of the so called 'genealogical paradigm' that foregrounded a focus on patterns of descent in the early $20^{\text {th }}$ century origins of anthropology has moved in the $21^{\text {st }}$ century from being thoroughly critiqued to being recentered, but in a way that encompasses a much more expansive lens of inquiry. This has raised novel theoretical and methodological questions and opened new avenues of ethnographic investigation 
concerning how kin are constituted and the meaning and significance of 'relatedness'. This includes questioning the narrow 'domaining' of kinship to the domestic and private sphere and its assumed irrelevance to institutions and practices of modern societies (McKinnon and Canell 2013, Bear 2013, Lambeck 2013), as well as much more widespread recognition of the fluidity and flexibility in the meaning of both social and biological kin making. While the so called 'genealogical paradigm' persists, there is increasing emphasis on the need to move beyond the dichotomy and dualities between biology and culture that have informed so much work in the field of kinship studies.

Critiques challenging the universality of this biology-culture distinction have been foundational to disciplinary orientations toward kinship, including in the work of Schneider (1981) and longstanding feminist anthropological engagement (MacCormack and Strathern 1980; Yanagisako and Collier 1995; Franklin 2001; Franklin 2019). The potential for a greater and more productive reflexive rapprochement between the biological and social in the contemporary moment of rethinking kinship and relatedness is something that contributors to this series are centrally concerned with. They examine both the novel terrain across which this possibility is unfolding within the biosocial sciences and the increasing entanglements between the biological, social and environmental exposures in multigenerational lives. By engaging with the fundamental importance of relations to all aspects of social and political worlds found within the biosocial and environmental sciences, this special issue asks if an intergenerational ethnography might speak back to and extend the scope and relevance of kinship studies within and beyond medical anthropology.

The need to overcome the ongoing tension between what have been seen as 'old and new' approaches to kinship (Bamford 2019) is increasingly gaining ground in the discipline (See Carsten 2020; Sahlins 2013; Trautmann et al 2011). This come through in attention to 'being and doing' or the practice or performative aspects of kinship as opposed to its ascriptive 
dimensions (Carsten 2020, Mckinnon 2016). One arena where this focus has been generative is in rethinking the 'substance' of kinship and how it is variably materialised, in ways that include but are not limited to the biological. Building on the work of Yanagisako and Delaney (1995), who emphasised the diverse ways that kinship is naturalised and essentialised, numerous studies have responded to calls for more 'local' accounts of how 'essence, fixity and materialisation' are at stake in kin making (Mckinnon 2016). This has expanded anthropological inquiry not only to consider practices of eating, cooking or working as kinship, but also to think through the role of different bodily substances and objectifications of relatedness, in terms of food, land, houses, ancestral spirits or identity documents (Mckinnon 2016, Carsten 2019, Janowski 2007, Leach 2009). The contributions to this special issue further illuminate how intergenerational kinship is materialised by a variety of people (policy makers, gardeners, mothers, toxicologists, or family members of deceased relatives) in a number of substances (seeds, lettuces, faecal matter, epigenetic biomarkers or pesticides). The articles also crucially reflect on how and with what consequences these materializations and embodiments are made to appear universal, fixed or essential.

As Susan Mckinnnon points out, attending to the 'differences in degree of materialisation and objectification of kinship' is central to 'comprehending the structures and dynamics of hierarchy' (2016). In materializations of kinship through the biosocial sciences and environmental activism, questions of power and inequality are never far from view. For example, Michelle Pentecost's article describes the danger of a newly biologized reading of the intergenerational trauma of apartheid history in South Africa through contemporary public health approaches to violence prevention. Here, matters of kinship and power are deeply entangled. 
The 'substance' of kinship is also being rethought at its interface with temporality, especially through efforts to resituate anthropological inquiry across the life course and beyond the ubiquitous focus on birth and death (Lambeck 2013). As Carsten points out, temporality is a somewhat neglected component of the 'imaginative potential of kinship' (2019). For Carsten, the 'mnemonic properties of artifacts' at stake in kin dynamics, whether that concerns blood, houses, food, or photographs, facilitate an entry point for examining the varied contours and ruptures that constitute the 'thickening and thinning' of kin relations over time (2019 see also Cruz 2020). As the contributions to this collection outline, the scalar dimensions of epigenetic and environmental science, often refracted through a focus on intergenerational connections and diverse materialities, place questions of temporality and kinship centre stage. This is powerfully illuminated by Stephanie Lloyd and Alexandre Larivée's contribution, in which they discuss kinship and trauma in the 'afterlife' of death among families involved in epigenetic research on suicide risk. Here, while epigenetic research maps a temporality that extends beyond a single generation, such research is also characterised by linear and individuated 'metonymic reasoning.' This linear, individuated reasoning stands in contrast to the experiences of family members, who must grapple with the ambivalent and volatile 'residues' of trauma in the always unfinished task of 'caring for the dead'.

Of equal relevance to this special issue is recent engagement with a classic theme in kinship studies: the notion of descent. While this terms' use and meaning has shifted over time, as Feeley-Harnik points out, questions of inclusion, exclusion and discrimination have been ever present in anthropological discussion of descent (2019). Early modern theories of heredity in which boundaries between bodies and places were not so tightly drawn, but instead mutually 'engendered' (Lopez Beltran 2007; see also Meloni 2019), seem to have increased relevance in an era of environmental epigenetics. The contemporary contingencies of social contexts and environment across 'the lifecourse' and between 
generations become the new currency of biosocial research, generating new questions and concerns. As a result the assumption that there a pre- $18^{\text {th }}$ century notion of 'generation' embedded in humoural thinking about bodies as conditionally shaped through environments has been straightforwardly replaced with a conceptualisation of 'heredity' focused on biological units of transmission (Jacob 1973, Muller-Wile and Rheinberger 2012) may now be losing traction. Indeed historical analysts of these earlier transformations in thinking about heredity document how these changes were piecemeal, partial, slow to develop, and encompassed a range of disciplinary and social spheres of life from science of breeding to philosophy and the growth of empire (Muller-Wille and Rheinberger 2007, 2012). The lasting significance of any recursive turn in conceptual thinking about heredity and generation in the new fields of biosocial science is as such still uncertain and actively unfolding. For example, as Martine Lappe and Robbin Jeffries Hein's contribution discusses, while epigenetic research can foreground the effect of social experiences on neurodevelopment and behaviour, it also often preserves a gendered mother-dyad focus that abstracts the dynamic impact of structural inequalities. This, in turn, results in a 'temporal embedding' that newly biologizes early adversity.

At the same time, it is possible to see how ideas of inheritance are now being creatively redefined by contemporary communities. Such reworkings have the potential to transform the substance and scope of heredity. The 'in-situ' seed saving practices of gardeners and activist communities in London examined in the contribution to this special issue by Katharine Dow reveals how seeds' capacity to embody environments constitutes their inherent malleability and relationality as a form of intergenerational kinship. Such intergenerationality is both celebrated and sought in pursuit of biodiversity; a practice of 'denaturing' that stands in contrast to the 'pure line' model of heredity of industrialised model of seed production. Similar re-definitions are also powerfully illustrated in the work of other anthropologists such as Angela Garcia, who examines how heroin addiction is perceived as 
a form of inheritance moving between and seeping into the lives of multiple generations in New Mexico (2014). Framed as a contemporary form of 'querencia' (meaning inheritance or belonging referring to both property or also 'love of the land'), Garcia's work demonstrates how such an intergenerational understanding has both productive and destructive consequences (2014:101). Kinship ambivalence is also outlined in a recent special issue of Ethnos edited by Lotte Meinert and Lene Grøn (2019). Productively unpacking what and how things 'run in families,' they consider kinship and descent through the productive prism of contagion to examine "how intergenerational transmissions are experienced, how they are constituted and what they comprise' (2019: 584). Furthering a collective effort to move beyond the distinctions between social and biological, their discussion of 'contagious kinship' illuminates how intersubjectivity and indeterminacy, as well as ambivalence, are defining elements of understanding cross and inter-generational inheritance.

While new ways of thinking about descent and heredity are now emerging, it is nevertheless also true to say, as Sarah Lamb points out (2015), that the notion of 'generation' has not yet been widely used in anthropology. This is despite evidence of its utility as a 'powerful analytical lens for studying society' (Alber et al 2008), including key themes such as 'modernity' or 'care' (Cole and Durham 2007) and recognition of its specific political relevance in identified national contexts (Comaroff and Comaroff 1999). It is a conceptual terrain which has particular relevance in this lived moment of the global pandemic caused by the novel coronavirus Covid-19, which has and continues to have devastating impact for families and communities. Both the disease and the consequences of efforts to control the virus are having drastic generational and inter-generational consequences (Cohen 2020). It is a time when Sophie Day's notion of 'demographies' in flux' (2012) seems particularly apposite, and when examining social reproduction or 'social heritage' (Meinert and Gron 2019), as this concerns intergenerational transmission and dynamics through the lens of ethnography, is particularly urgent. 
Critical reflections on the meaning of kinship studies for the discipline have frequently drawn on Ladislav Holy's important idea that 'new insights into kinship have been gained as they are always gained through shift[s] in contextualisation' (1996:6) (see also Franklin and McKinnon 2013 and Bamford and Leach 2009). In the rest of this introduction, we expand on this point to critically examine how particular shifts in contextualisation, relating to the emergence of a discourse of epigenetic inheritance and the embodied intergenerational impact of environmental exposures, provide new methodological and theoretical opportunities and challenges for how we rethink kinship in intergenerational times.

\section{(Epi)genetic inheritance and intergenerational relatedness}

This special issue contributes to a growing focus of ethnographic attention on the emerging terrain of epigenetic science (Landecker and Panofsky 2013). Authors use the lens of ethnography to understand what aspects of the biological and social materialise and transform the meaning of intergenerational transmission in the context of epigenetic research. Articles included here focus not only on scientific findings but also research methodologies and modes of research subject recruitment in epigenetic inquiry, and in how epigenetic knowledge is translated into public health. Contributors consider how the 'literalisation' (Strathern 1992) of intergenerational relatedness in the context of epigenetic research in cohort studies dynamically informs the doing of biosocial science, as well as the structural inequalities that continue to shape global health and research participation.

Cross-generational transmission, mostly centered on fetal and maternal environments, has become a focus of social science inquiry, and critical engagement has been acutely attuned to the gendered norms of blame and responsibility (Richards 2015, Kenny and Muller 2017). As Lloyd and Larivée's contribution points out, the family is now viewed as a particular 
"ecology of risk and repair"; a dynamic socio-historical context of inter- and crossgenerational relations that is seen as directly shaping future biological and social health outcomes. Other contributions similarly reflect on how ideas of the intergenerational family move across domains of expert knowledge and get folded into policies informed by epigenetic research, for instance in social policy discussion concerning violence and health prevention in South Africa as analyzed by Michelle Pentecost, and as compared to lived experiences of oppression in the U.S., as discussed in the work of Martine Lappé and Robbin Jeffries Hein. In such studies, questions of the 'life-course' are placed centre stage. Early exposures to social and biological environments become reconfigured as vital to the shaping of mental and physical health later in life, reconfiguring the temporal terrain of genomics and epigenetic inquiry (Lappé and Landecker 2015).

Questions concerning 'adversity' and 'resilience', particularly in childhood, are foregrounded in epigenetic research defined by certain forms of social experience and exposures. But as noted by Lloyd and Raikhel (2018) 'adversity' frequently becomes black boxed, singular and homogenised in epigenetic research that focuses on identifying the biomarkers and biosocial pathways that link these early experiences to later life health outcomes and mental wellbeing. These aspects of epigenetic research are of central significance for many contributors to this special issue as they critically examine how and with what consequences the 'flattening' of social and biological factors (Landecker and Panofsky 2013) transform the meaning and scope of intergenerational relatedness. This is particularly evident in the contribution by Lloyd and Larivée examining epigenetic research focused on the relationship between exposure to adversity in childhood and suicide risk where the role of different generations of kin is central to psychological autopsies. It is also relevant in the work of Pentecost examining how different generational experiences of adversity, in this case social experiences of post-apartheid violence in South Africa, are central to social policy shaped by a focus on the biological imprinting for future lives. 
Longitudinal birth cohort studies often aim to include two or more generations of participants to examine the epigenetic effects of social and environmental exposures in "early life," including preconception. They provide an important context and resource for biosocial research, but also act as a 'technology of' the biosocial (Gibbon and Pentecost 2019). ${ }^{1}$ At the same time the expanding relevance of the $\mathrm{DOHaD}$ hypothesis (Developmental Origin of Health and Disease) across a range of global health interventions, which typically focus on family social relations in the 'First 1,000 days of life', provide another site of inquiry for the shifting focus on intergenerational dynamics. This raises important concerns about how a gendered maternal responsibility for the health of future generations is being underlined in global health (Pentecost and Ross 2019). As Emily Yates Doerr points out, while the focus of these and related global health initiatives has seemingly shifted from individual bodies and questions of choice to a broader context of intergenerational relations, the 'social' at stake continues to be often narrowly defined and unidirectional (2020; see also Valdez 2018).

Anthropologists are also considering how epigenetic science and other biosocial sciences have the potential to articulate a wider politics concerning intergenerational inheritance as this relates to colonial legacies and histories of trauma and abuse. As Kim TallBear points out, there are long standing concerns about how science, including genetics (and now also now epigenetics) has been used to define, discriminate and itself cause harm in Indigenous communities (2013). Nevertheless, the potential use of epigenetic science as a resource in materialising the emotional and physical trauma of historical colonialism in some cultural arenas is an emerging area of anthropological inquiry. In their work among Aboriginal communities, Megan Warin and colleagues examine how epigenetics can provide a

\footnotetext{
${ }^{1}$ They are also an emerging site of inquiry and intervention for novel ethnographic research as demonstrated by the work of the recently established Biosocial Birth Cohort Research Network by Sahra Gibbon at UCL that includes anthropologists, political scientists and epidemiologists
} 
powerful means of articulating and politicising embodied intergenerational inequalities (2019). In some contexts, such as the situations of toxic industrial exposure in Nanjing, China, discussed by Janelle Lamoreaux, epigenetic thinking may have the potential to bring about accountability for environmental harm. In other contexts, such as those discussed by Pentecost, a generalising concept of 'epigenetic trauma' that is abstracted from sedimented histories of colonialism and uneven social infrastructure undermines the potential for reparative justice.

\section{'Chemical Kinship', Toxic Relations and Exposed Biologies}

While there is a long history of activism and scientific inquiry concerning the embodied and intergenerational effects of chemical pollutants (Carson 1962), this work has taken on an increased urgency in an era of accelerating and increasing degradation of the environment through global expansion of industrial and chemical industrial infrastructure. Anthropologists have responded by identifying novel chemical objects and social contexts of inquiry to examine how they contribute to but also disrupt the reproduction and the maintenance and survival of kin (Hoover 2017, Murphy 2008). The work of anthropologist Vanessa AgardJones in examining the role of endocrine disruptors in the Caribbean has demonstrated the extent to which attention to questions of toxicity and exposure bring to the fore shared violence and harm. Here what Agard-Jones describes as 'chemical kinship' (2016) highlights a 'cynical' form of relatedness, where community is built through harm. Chemical kinship has also been discussed as a move away from an anthropological focus on lineage toward a feminist and anticolonial "tentativeness towards making normative claims about chemicals because, like kin, these materials are never entirely good nor bad" (Balayannis et al 2020).

Reflecting many communities growing concerns about toxicity and 'exposed biologies' (Wahlberg 2018), contributors to this special edition examine how people are studying and thinking through the intergenerational effects of chemical contamination, inheritable 
environments, and the sometimes ambivalent and violent nature of kinship (Franklin and McKinnon 2001). If intergenerational relations are understood not only as occurring through blood and genes, but also through seeds, industrial chemicals and microbiomes, how are the environmental and economic problems of late capitalism making and unmaking kin? Janelle Lamoreaux's contribution discusses how the rise of what has been called 'generational toxicology' has led to an increased focus on the intergenerational effects of chemical exposures. Conducted through genotoxicity, epigenetic and birth cohorts studies, such science raises questions about the how the idea of 'passing down pollution' gets materialized in practice. Such science also raises important questions for anthropological reflection - on both the possibilities of understanding kinship in and through environments, as well as the risks of reproducing developmental and gender norms through research.

The meaning of toxicity for intergenerational relations and kin is also being shaped by diverse histories. Foregrounding varied histories of the 'biosocial' (Meloni 2019), including indigenous knowledge and alternative nature-culture understandings (Escobar 2016), is vital to articulating the expanding possibilities for intergenerational ethnography in urgent social, political and environmental times. Lamoreaux (2016) has referred to such history as 'epigenetic lineages' (2016). In her earlier work, constituting the environment 'as a person' in Chinese toxicology science does not entail a repertoire of cultural meanings that individualizes (maternal) blame, but instead reflects different histories of science and personhood that can point to alternative idioms and contexts of collective responsibility (Lamoreaux 2016). Such attentiveness is also central to the work of Elizabeth Hoover, who demonstrates in her ethnographic work in the Mohawk community of Akwesasne how exposure to the environmental contaminant PCB, itself a product of unequal distribution of industrial waste, has facilitated community efforts to reclaim reproduction in 'de-colonized' terms (2017). In this special issue, Amber Benezra's contribution on transnational microbiome research shows how microbes are increasingly being reimagined as kin, which 
are made and unmade through multiple environments of exposure. Further she asks readers to consider how social scientific renderings of microbes as kin often elide the Indigenous cosmologies from which they implicitly draw. Here, relations are absences; the result of overlooked scholarship, institutional hierarchies, and unequitable knowledge making processes that go beyond the world of microbial science to medical anthropology itself. Such research shows that attentiveness to modes of 'kinfullness' (Benjamin 2018) that pre-exist or are reconfigured by studies of environmental exposures is important for thinking through the possibilities of "being in good relations" (Tallbear 2018).

Questions of stratification are central to much of this arena of inquiry and remain a core concern for the contributors to this special issue. Inequitable infrastructures of power and resources shape the intergenerational possibilities of (un)making kin. Building on the insights of Donna Haraway (1990) and Sarah Franklin (2013), who have consistently emphasised how reproduction is a process that does not 'just end at the skin' or 'in the body', the work of Michelle Murphy $(2008 ; 2013 ; 2017)$ has been vital in attending to the modes of 'distributed reproduction' that move far beyond individual bodies. For Murphy, this includes the transgenerational and temporal effects of not only 'chemical infrastructures' but also 'state, military, agriculture and economic architectures... of capitalism and colonialism (2018; see also Murphy 2013). What is required, she argues, is an ability not only to track this complex dynamic but also to examine 'how it unfolds, is contested, regulated and lived' (2018). Others are now responding to this challenge by considering how questions of toxicity, power and justice in diverse global arenas are inseparably entangled (Liboiron 2018; Agard-Jones 2016).

Importantly, this recognition may not only precipitate novel modes of healing (Langwick 2018) but also what Ticktin (2019) refers to as 'speculative futures of care,' an expansive mode that can engage questions of social justice and biological ecologies at different scales. 
At a moment of global attention, including youth activism around climate change and environmental inheritance, a key question is whether intergenerational influences of toxic exposures become an effective means of galvanizing hope and care for future generations and across species. Addressing uneven and inequitable toxic relationalities and exposed biologies is a significant challenge for anthropology and ethnography, and of central concern for contributors to this special issue.

\section{Outline summary of papers}

Kinship, place and intergenerational transmission are productively aligned in Katie Dow's examination of seed saving practices among environmental activist communities in London. Dow demonstrates not only how idioms of kinship, care and parenting are put to work, but also how in-situ seed saving, sharing and swapping becomes itself a vehicle for sustaining intergenerational kin relations. Moving beyond the framework of gene fetishism, the practices outlined in this article bring to light new 'alternative' kin making practices and imaginaries that emerge with and through plants, environments and people. In contrast to the 'de-natured' commercial seeds whose origins are often obscured it is the 'embodied ecologies' (Ford 2019) of seeds which are foregrounded as 'always bringing their worlds with them' in these activist communities. Drawing a parallel with Strathern's theorisation of individuality and diversity in English kinship we see how 'accretion of diversity' is also at work in seed saving practices, where individual seed entities become relationally embodied by their growing environments. The 'bloody marvel' lettuce (its naming wonderfully evoking local ecological origins) and the social practices that produce it point to the emphasis among local seed saving communities on sustaining biodiversity and inherent malleability in the always embodied relationship between seeds and their environments.

Like seeds, the focus on microbes in Amber Benezra's contribution also challenges us to rethink the constitution of bodies, environments and kin as embodied ecologies that are in 
infinitely entwined in both multi-species and intergenerational forms. Drawing on her work examining microbial science in the US, and also field research with a birth cohort study in Mirpur Dhaka focused on nutrition and the microbiome, she evokes the idea of environmental kin. Centering kincentric ecologies from Indigenous studies, Benezra discusses issues of reciprocal accountability in more-than-human relations and citational politics. Ultimately, understanding microbes as kin points to new challenges and opportunities for biosocial research and interdisciplinary dialogue, opening up questions about how family, food, healthcare and socioeconomic inequality become intergenerationally linked.

Janelle Lamoreaux's article also focuses on non-human kin by thinking with and against toxicologists who study the intergenerational effects of exposures. Based on research conducted in China, Lamoreaux emphasizes how different approaches to gene-environment interaction research bring forth an idea of inherited toxicity that finds meaning in a context where both national population quality and the continuity of familial lineage are stressed. Such intergenerational methods, then, not only show how central ideas of (epi)genetic inheritance, heterosexual reproduction and normative sexual development are to toxicology. They also show the possibilities that may unfold from within environmental science and activism by considering toxic non-human substances as kin.

The focus on epigenetic research, particularly related to the consequences of traumatic or violent early life experience and 'adversity' in intergenerational kin relations are foregrounded in each of the remaining contributions to this special issue.

This includes Martine Lappe and Robbin Jeffries Hein's examination of epigenetic science in the US and Canada focused on exposure to early adversity, trauma stress. They illuminate how telescoping in on this life stage, whilst potentialized as a form of social and political 
intervention on development processes, also omits broader historical conditions and social structures. They outline how the methodological limits of focusing on early life experiences results in a 'temporal embedding of experience' and ultimately a 'biologisation' of early caregiving environments. In the context of North American histories of inequalities, repression and subjugation such research ultimately, they argue, reproduces gendered notions of kinship that narrow the locus of epigenetic research to discrete relationships (mostly mother-child dyads), and biomarkers. They make a powerful case for ethnographic intervention that can recalibrate the emerging epigenetics of exposure to early adversity in ways that include wider historical and social dynamics.

Resisting a newly biologized rendering of trauma is also the focus of Michelle Pentecost's discussion drawing on ethnographic research in Khayelitsha in Cape Town, South Africa where epigenetics is being speculatively inflected and resourced as an embodied manifestation of apartheid history in the context of violence prevention programmes. Moving from a focus on epigenetic science to policy and public discourse Pentecost, like other contributors, points to the dangers of an epigenetic lens, centred here on examining cycles of violence in poor communities in South Africa. We see how translating trauma into data points and biomarkers 'simplifies' complex histories of apartheid violence. Ethnographic research with a cohort of families in the region further illustrates how the anticipatory logics of prevention that emerge from epigenetic framings of trauma shape the gendered investments of kin and families, manifested in this case as extreme anxiety concerning male children. Making use of feminist relational ethics she contests the 'easy default' of molecular explanations and approaches which effectively contribute to the very cycles of violence they aim to prevent by occluding the 'social sedimentations' of colonialism, gender norms and racialization. 
The devastating and tragic effects of early trauma are also the focus on Stephanie Lloyd and Alexandre Larivée's examination of epigenetics of suicide risk among families in Canada, as part of their research with the McGill Group for Suicide Studies (MGSS), making use of ethnographic interviews with families whose deceased relatives have died in this way. While the brains of these individuals are the focus for epigenetic studies of suicide risk, the relatives of those who have died nonetheless have an essential role, acting as a 'proxy' for the dead in providing retrospective accounts of the deceased person's life for the researchers as part of a psychological autopsy. For both families and scientists, the 'afterlife of death' shapes their experiences and understanding. Yet the individuated linear models of kinship and trauma 'inscribed' on the MGSS rendering of suicide risk stand in contrast to the relational and shared narratives of trauma and care that shape families' experiences. The processual, subjective entanglements of life always lived 'in post' evoke diverse articulations of 'chemical kinship' (Agard-Jones 2016), where the legacy of toxic relationalities and care are hard to disentangle, forming 'residues' that shape lives and social relations across multiple timescales. Here, traversing a tension between 'preserving' and 'following' the dead in making sense of the past and the future we see how families enrolled into epigenetics research of suicide risk struggle to align the linear, often negative and individualising narrative of neurobiological risk with their own unending efforts to understand the reasons for family member's suicide.

\section{Conclusion}

In reflecting on how genes, microbes, sperm, seeds and other bio substances absorb and reflect environments and exposures of many types, the papers in this special issue foreground what anthropology's long tradition of kinship studies brings to a burgeoning popular and scientific interest in cross- and inter-generational transmission, inheritance and interdependencies. They also consider how ethnography might inform and also itself be informed by such intergenerational research. This special edition underlines that 'staying 
with the trouble' (Haraway 2016) of ethnographic engagements that centre on how and with what consequences intergenerational kin are being made and unmade in terrains that encompass and connect biosocial research and environmental change is paramount. This is an increasingly vital task as we join others in thinking about how to both simultaneously resist and retool kinship as an analytic in 'intergenerational times'.

\section{Bibliography}

Alber, E., van der Geest, S., Whyte, S.R. (Eds.), 2008. Generations in Africa:

Connections and Conflicts. LIT Verlag, London.

Agard- Jones, V (2016) Ep 35 Cultures of Energy Podcast. CENHS September 29th http://culturesofenergy.com/ep-35-vanessa-agard-jones/

Agard-Jones, V. (2013) Bodies in the System. Small Axe 17(342) 182-192

Bamford, S (ed) (2019) The Cambridge Handbook of Kinship. Cambridge University Press

Bamford and Leach (2009) Kinship and Beyond: The Genealogical Model Reconsidered. New York, Oxford: Berghahn Books.

Balayannis, A. \& Garnett, E. (2020). Chemical Kinship: Interdisciplinary Experiments with Pollution. Catalyst: Feminism, Theory, Technoscience, 6(1), page 1-10.

Benjamin, R. (2018) ‘Black AfterLives Matter: Cultivating Kinfulness as Reproductive Justice.' In Clarke, Adele E. and Donna Haraway (eds.) Making Kin Not Population. Chicago: Prickly Paradigm Press. 
Briggs, L. (2017) How all Politics Became Reproductive Politics From Welfare Reform to Foreclosure to Trump. Oakland: University of California Press.

Bunkley, E. (2021) Diabetic Living: Senagalese Women's Experiences with Metabolic Illness. University of Arizona, PhD Dissertation.

Carson, R. (1962)(2000) Silent Spring. London: Penguin Modern Classics.

Carsten, J. (2020) 'Imagining and living new worlds: The dynamics of kinship in contexts of mobility and migration', Ethnography 21 (3): 319334.

Carsten, J. (2019) 'The Stuff of Kinship' in Bamford (ed) The Cambridge Handbook of Kinship. Cambridge University Press: 133-150.

Choy, T. (2011). Ecologies of Comparison: An Ethnography of Endangerment in Hong Kong. Durham: Duke University Press.

Cohen, L. (2020) “The Culling: Pademic, Gerocide, Generational Affect," Medical Anthropology Quarterly 34 (4): 542-560.

Cruz, R. (2020) "Siblingship beyond siblings? Cousins and the shadows of social mobility in the central Philippines" Journal of the Royal Anthropological Institute 26(2): 321-242.

Clarke, A.E. and Haraway, D. (eds.) Making Kin Not Population: Reconceiving Generations. Chicago: Prickly Paradigm Press, 2018.

Cole, J., Durham, D. (Eds.), 2007. Generations and Globalization: Youth, Age, and Family in the New World Economy. Indiana University Press, Bloomington, CA. 
Comaroff, J., Comaroff, J.L., 1999. Occult Economies and the Violence of Abstraction: Notes from the South African Postcolony. American Ethnologist 26(2), 279-303.

Dow, K. (2016). Making a Good Life: An Ethnography of Nature, Ethics and Reproduction. Princeton, N.J.: Princeton University Press.

Dow, K., \& Lamoreaux, J. (2020). Situated Kinmaking and the Population "Problem". Environmental Humanities, 12(2), 475-491.

Escobar, A. (2016) Thinking-feeling with the Earth: Territorial Struggles and the Ontological Dimension of the Epistemologies of the South. Revista de Antropología Iberoamericana 11(1): 11-32.

Feeley-Harnik, G. (2019) “Descent in Retrospect and Prospect.” In The Cambridge Handbook of Kinship. Bamford, S (ed). Cambridge University Press, 51-87.

Ford, A. (2019) "Embodied Ecologies." Theorizing the Contemporary, Fieldsights, April 25. https://culanth.org/fieldsights/series/embodied-ecologies

Fortun, K. (2016) “Ethnography in Late Industrialism." Cultural Anthropology 27(3): 446-464.

Franklin (2019) 'The Anthropology of Biology. A Lesson from the New Kinship Studies' in The Cambridge Handbook of Kinship. Bamford, S (ed). Cambridge: Cambridge University Press: $107-132$

Franklin, S (2013) Biological Relatives. IVF, Stem Cells and the Future of Kinship. Durham: Duke University Press. 
Franklin, S. (2001). Biologization Revisited: Kinship Theory in the Context of the New Biologies. In Relative Values: Reconfiguring Kinship Studies. Franklin, S. and McKinnon, S. (eds.) Durham: Duke University Press, pp. 302-326.

Franklin, S. and McKinnon, S. (eds.) (2001) Relative Values: Reconfiguring Kinship Studies. Durham: Duke University Press.

Garcia, A (2014) "Regeneration: Love, Drugs and the Remaking of Hispano Inheritance" Social Anthropology 22 (2): 200-212.

Gilbert, S. F., J. Sapp, and A. I. Tauber. 2012. A Symbiotic View of Life: We Have Never Been Individuals. Quarterly Review of Biology 87: 325-41.

Gibbon, S. and Pentecost, M. (2019) Excavating and (re)creating the biosocial: birth cohorts as ethnographic object of inquiry and site of intervention. Special Series in Somatosphere, November. http://somatosphere.net/2019/introduction-excavating-and-recreating-thebiosocial-birth-cohorts-as-ethnographic-object-of-inquiry-and-site-of-intervention.html/

Gordon, D. 1988. "Tenacious Assumptions of Western Medicine." In Biomedicine Examined, Lock M. and Gordon, D. (eds.). Dordrecht: Kluwer Academic: 19-56.

Haraway, D. J. 2015. Anthropocene, Capitalocene, Plantationocene, Chthulucene: Making Kin. Environmental Humanities 6: 159-65.

Haraway, D. (2016) Staying with the Trouble. Making Kin in the Chthulucene. Durham. Duke University Press.

Haraway, D. (1991)Simians, Cyborgs and Women. The Reinvention of Nature. Routledge. 
Hoover, E (2017) The River Is in Us: Fighting Toxics in a Mohawk Community. Minneapolis: Univ. Minn. Press.

Hoover, E. (2018) 'Environmental Reproductive Justice: intersections in an American Indian community impacted by environmental contamination'. Environmental Sociology, 4(1): 8-21.

Holy, L. (1996) Anthropological Perspectives on Kinship. London. Pluto Press.

Janowski, M (2007) Introduction: Feeding the right food: The flow of life and the construction of kinship in Southeast Asia' in M. Janowski and F. Kerlogue (eds), Kinship and Food in South East Asia, Copenhagen: Nordic Institute for Asian Studies

Kaufman, S. and Morgan, L. (2005) 'The Anthropology of Beginnings and Ends of Life’. Annual Review of Anthropology 34 (1): 317-41.

Kenney M. and Müller R. 2017. Of rats and women: narratives of motherhood in environmental epigenetics. BioSocieties 12(1):23-46.

Lamb, S. (2015) 'Generation in Anthropology' International Encyclopaedia of Social and Behavioural Sciences, Second Edition: 853-856.

Lambeck (2013) 'Kinship, modernity, and the Immodern. In S. McKinnon \& F. Cannell (eds) Vital relations: modernity and the persistent life of kinship , 241-60. Santa Fe, N.M.: SAR Press.

Lamoreaux, J. (2016) "What if the environment is a person? Lineages of epigenetic science in a toxic China" Cultural Anthropology 31(2): 188-214.

Langwick S,A. 2018. "A politics of habitability: plants, healing, and sovereignty in a toxic world." Cultural Anthropology. 33(3): 415-43. 
Landecker H, Panofsky A. (2013) From social structure to gene regulation, and back: a critical introduction to environmental epigenetics for sociology. Annual Review of Sociology 39: 333-57.

Lappé, M., Jeffries Hein, R and Landecker, H. (2019) "Environmental Politics of Reproduction." Annual Review of Anthropology 48: 133-150.

Lappé M. and Landecker H. (2015). How the genome got a life span. New Genetics and Society. 34(2): 152-76.

Last, M. (2019) Medical Ethnography over Time. Penetrating the 'fog of health' in a Nigerian community, 1970-2017. Anthropology in Action 26 (1): 52-60.

Leach, J. (2009) Knowledge as kinship: Mutable essence and the significance of transmission on the Rai Coast of Papua New Guinea' in S. Bamford and J. Leach (eds), Kinship and Beyond: The Genealogical Model Reconsidered, New York: Berghahn.

Leighton, M. \& Roberts, E. F. S. (2020). Trust/Distrust in Multidisciplinary Collaboration: Some Feminist Reflections. Catalyst: Feminism, Theory, Technoscience 6 (2), 1-27.

Llloyd, S. and Raikhel, E. (2018) 'It was there all along': situated uncertainty and the politics of publication in environmental epigenetics' Biosocieties 13: 737-760.

Lloyd, S and Muller, R (2018) Situating the Biosocial: Empirical Engagements with Environmental epigenetics from the lab to the clinic. BioSocieties 13: 675-680.

Lorimer, J. (2018) 'Hookworms Make Us Human: The Microbiome, Eco-Immunology and a Probiotic Turn in Western Health Care. Medical Anthropology Quarterly 33(1): 60-79. 
Lynch, C. and Danely, J. (eds) (2013) Transitions and Transformation: Cultural Perspectives on Aging and the Life Course (Life, Course, Culture and Aging). New York, Oxford: Berghahn Books.

McKinnon, F. and Canell, F. (eds) (2013) Vital relations: modernity and the persistent life of kinship, 241-60. Santa Fe, N.M.: SAR Press.

McKinnon S (2016) Doing and being: Process, essence, and hierarchy in making kin. In: Coleman S, Hyatt SB and Kingsolver A (eds) The Routledge Companion to Contemporary Anthropology. London and New York: Routledge, pp. 161-182.

Meinert, L and Grøn, L (2019) 'It Runs in the Family'. Exploring Contagious Kinship Connections." Ethnos, 85(4): 581-594.

Meloni, M. 2019. Impressionable Biologies: From the Archaeology of Plasticity to the Sociology of Epigenetics. New York: Routledge.

Müller-Wille, S and Rheinberger, H (ed) (2007) Heredity Produced. At the Crossroads of Biology, Politics and Culture 1500-1870. Boston: MIT Press.

Murphy, M. (2018). "Against Population, Towards AlterLife." In Clarke, Adele E. and Haraway (eds.) Making Kin Not Population. Chicago: Prickly Paradigm Press.

Murphy, M. 2017. Alterlife and Decolonial Chemical Relations. Cultural Anthropology 32: 494-503.

Murphy, M (2013) Distributed Reproduction, Chemical Violence and Latency, Scholar and Feminist Online 11(3). 
Richardson, S. (2015) Maternal Bodies in the Postgenomic Order: Gender and the Explanatory Landscape of Epigenetics in Postgenomics: Perspectives on Biology after the Genome. Richardson, S. and Stevens, H. (eds). Durham: Duke University Press.

Rofel, L. (1999) Other Modernities: Gendered Yearnings in China After Socialism. Berkeley: University of California Press.

Pentecost, M and Ross, F. (2019) "The First Thousand Days: Motherhood, Scientific Knowledge and Local Histories." Medical Anthropology 38 (8): 747-761.

Roberts, E. F. S. (2019). "Bioethnography and the Birth Cohort: A Method for Making New Kinds of Anthropological Knowledge about Transmission (Which Is What Anthropology Has Been about All Along)." Somatosphere (blog). November 19, 2019.

http://somatosphere.net/2019/bioethnography-anthropological-knowledgetransmission.html/.

Sahlins, M (2013) What Kinship is and Is Not. Chicago: University of Chicago Press.

Sasser, J. (2018) On Infertile Ground: Population Control and Women's Rights in the Era of Climate Change. New York: NYU Press.

Schneider, D. (1980) American Kinship. A Cultural Account. Chicago: University of Chicago Press.

Solomon (2016) Metabolic Living: Food, Fat and the Absorption of Illness in India. Durham: Duke University Press. 
Towards Intergenerational Ethnography 30

Strathern, M. (1992) After Nature: English Kinship in the Late Twentieth Century.

Cambridge: Cambridge University Press.

Subramaniam, B. (2018) “'Overpopulation' Is Not the Problem.” Public Books, November 27. www.publicbooks.org/overpopulation-is-not-the-problem/.

TallBear, K. (2013) Native American DNA: Tribal Belonging and the False Promise of Genetic Science. Minneapolis: University of Minnesota Press.

TallBear, K. (2018) "Making Love and Relations beyond Settler Sex and Family." In Making Kin Not Population: Reconceiving Generations. Clarke, A. E. and Haraway, D. (eds), 14564. Chicago: Prickly Paradigm Press.

Ticktin, M (2019) "From the human to the planetary: Speculative futures of care." Medicine Anthropology Theory 6(3): 130-166.

Todd, Z. (2016). An Indigenous Feminist's Take on the Ontological Turn:'Ontology’is just another word for colonialism. Journal of Historical Sociology 29(1), 4-22.

Trautmann T., Mitani J. and Feeley-Harnik G. (2011) “Deep Kinship.” In Deep History: The Architecture of past and Present. Shryock A. and Smail D.L. (eds). Berkeley: University of California Press, pp. 160-188.

Tsing, A., Swanson, H.A., Gan, E. and Bubandt, N. (eds.) (2017) Arts of Living on a Damaged Planet: Ghosts and Monsters of the Anthropocene, Minneapolis: University of Minnesota Press. 
Valdez, N. 2018. "The Redistribution of Reproductive Responsibility: On the Epigenetics of ‘Environment' in Prenatal Interventions”. Medical Anthropology Quarterly 32: 425-42.

Wahlberg, A (2018) 'Exposed Biologies and the Banking of Reproductive Vitality in China' Science, Technology and Society 23 (2): 307-323.

Warin, E., Kowal, E. and Meloni, M. (2019) Indigenous Knowledge in a Postgenomic Landscape: The Politics of Epigenetic Hope and Reparation in Australia. Science, Technology and Human Values 45 (1): 87-111.

Yan Y. (2009) The Individuation of the Family in Rural China. Oxford: Oxford University Press.

Yanagisako, S. J., \& Collier, J. F. (1987). Toward a Unified Analysis of Gender and kinship. In Essays toward a unified analysis. Collier, J. F. and Yanagisako S. J. Gender and kinship: Essays toward a unified analysis. Stanford University Press, 14-50.

Yates-Doerr, E. (2020) "Reworking the Social Determinants of Health: Responding to Material-Semiotic Indeterminacy in Public Health Interventions." Medical Anthropology Quarterly 34(3): 378-397. 